\title{
Assessment of Noise Level during Ganesh Festival in Residential Zone of Kolhapur City
}

\author{
C. P. Sathe, A. M. Kadam, K. D. Ahire \\ Department of Environment Management, Chhatrapati Shahu Institute of \\ Business Education and Research, University Road, Kolhapur, Maharashtra, India
}

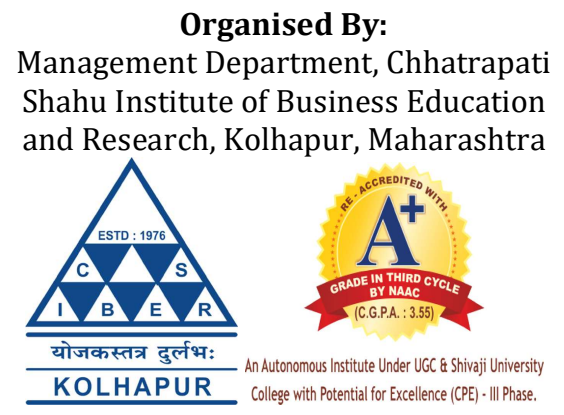

How to cite this paper: C. P. Sathe / A. M. Kadam / K. D. Ahire "Assessment of Noise Level During Ganesh Festival in Residential Zone of Kolhapur City" Published in International Journal of Trend in Scientific Research and Development (ijtsrd), ISSN: 2456-6470, Special Issue / Fostering Innovation, Integration and Inclusion Through Interdisciplinary

Practices in

Management, March

2019, pp.126-128,

URL:

https://www.ijtsrd.co

$m /$ papers/ijtsrd2308

2.pdf

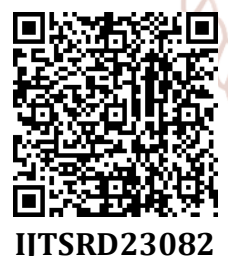

\section{ABSTRACT}

The present work deals with the study of noise level during Ganesh festival in residential zone of Kolhapur city. In recent time city is facing noise pollution problems during festival due to increased population, use of high volume systems \& modernized man-made human activities. The present work is being carried out at the Department of Environment Management, Chhatrapati Shahu Institute of Business Education \& Research Kolhapur. Rajarampuri residential area is selected for monitoring of noise level during Ganesh festival. The noise level has monitored with the help of sound level meter SL-100 Leutron in decibel unit $(\mathrm{dB})$ and directly equivalent sound level is measured (Leq). The increasing noise level is compared to the limits prescribed by the Central Pollution Control Board (CPCB).

\section{KEYWORDS: City, Residential Zone, Sound Level Meter}

\section{Int INTRODUCTION}

The word "Noise" has derived from a Latin word "Nausea" meaning injury or hurt. Noise is unwanted sound. The sound is a form of energy. According to Harvall "Noise is an unwanted sound which increases fatigue and under some industrial conditions it causes deafness". The environment effect of noise depends not only on total energy but on sound's pitch or frequency and its time pattern. The apparent noise that is perceived by human ear depends on both the frequency and intensity of sound. The intensity of the sound is measured in decibels ( $d$ - deci meaning 10, B Bell after the name of scientist Alfred Grahm Bell).Technically, a decibel $(\mathrm{dB})$ is the amount of sound pressure that equals to 0.0002 microbars (energy of about -15 Watts).
Sound is measured in terms of sound pressure or sound intensity that is the quantum of sound energy which flows through unit area of the medium in unit time. It is measured in decibel (dB). (VijendraM. 2006)

The impact of noise generated during these festivals by various activities like bursting crackers, sound systems music systems etc., making negative impact in the environment. (Patel.N. L and P. P. Bhave 2014)

Rane, P, et. al (2012) the noise level recorded at 22 sites in Mumbai which were divided into 4zones based on location. The noise level ranged from $60 \mathrm{~dB}(\mathrm{~A})$ to $120 \mathrm{~dB}(\mathrm{~A})$ at day time and $68 \mathrm{~dB}(\mathrm{~A})$ to $100.5 \mathrm{~dB}(\mathrm{~A})$ at night time. Highest recorded reading was at Mahim station $\{100.5 \mathrm{~dB}(\mathrm{~A})\}$ on Diwali night. The noise level was compared with prescribed CPCB standards. The study conducted by Hunashal, R. B., and Patil, Y. B. in 2011 clearly reveals the alarming condition of noise pollution in Kolhapur city. Various noise level indices and noise level based on national criteria are studied determining the mitigation measures against noise pollution.

\section{Need of the Study:}

The changing environment as a result of industrialization, urbanization, increasing population, transportation and communication system has taken its toll by increasing the noise pollution. Noise pollution can be distinguished from other types of pollution due to its source and diffusion characteristics, which can adversely affect public health and environmental quality in an urban environment. Noise pollution, in recent years has drawn interest of the researcher worldwide due to its physiological, psychological, and chronic effect on human beings (Tripathi et.al.2006). Noise effects include impacts on mental and physical health as well as interference with indices of human comfort and emotions such as effect on sleep, conversation, frequency of 
induced state of annoyance, hearing loss, cardiovascular problems as well as steady mindset to support tasks performance (Singh \& Davar 2004). Therefore, assessing the problem and programming actions for controlling its adverse effects have become issues of immediate concern for community. The Noise Pollution Regulation and control Rules, 2000 have also been implemented by government of India in the recent past for the regulation and control of noise producing and generating sources. So there is a need of noise pollution monitoring.

The present ongoing work has been carrying out to study noise level during Ganesh festival in residential zone of Kolhapur city and to find out sources of noise pollution during Ganesh festival in residential zone of Kolhapur city.

\section{MATERIAL AND METHOD}

The present work deals with the study of noise pollution during Ganesh festival. The noise level monitoring is carried out in Rajarampuri of Kolhapur city, during Ganesh festival. Although rajarampuri is commercial as well as residential zone but this study deals with only residential zone.

The monitoring of noise was carried out at $4^{\text {th }}$ lane, Rajarampuri, Kolhapur. The noise was measured from 8 PM to 9 PM during the Ganesh festival for 10 days. Each day sixty readings are taken in one hour at one minute interval. The noise is monitored with the help of Sound level meter (SL- 100). The noise monitoring is carried out as per protocols given in Maiti, 2003. The sound level meter used for this study directly measured the equivalent sound level (Leq).

Formula to calculate Noise level :-

$$
\operatorname{Leq}=10 \log \sum_{10 i=1}^{n}\left(f_{i 10^{l i / 10}}\right)
$$

\section{RESULT}

Table 1: Noise Level Reading During Ganesh Festival in Residential Zone of Kolhapur City

\begin{tabular}{|c|c|}
\hline Date & Leq $(\mathrm{dB})$ \\
\hline $14 / 9 / 2018$ & 93.72 \\
\hline $15 / 9 / 2018$ & 84.61 \\
\hline $16 / 9 / 2018$ & 95.48 \\
\hline $17 / 9 / 2018$ & 76.11 \\
\hline $18 / 09 / 2018$ & 87.07 \\
\hline $19 / 9 / 2018$ & 67.06 \\
\hline $20 / 9 / 2018$ & 65.32 \\
\hline $21 / 9 / 2018$ & 87.54 \\
\hline $22 / 9 / 2018$ & 75.79 \\
\hline $23 / 9 / 2018$ & 93.66 \\
\hline
\end{tabular}

Table2. CPCB Noise Level Limits

\begin{tabular}{|c|c|c|c|}
\hline $\begin{array}{l}\text { Area } \\
\text { Code }\end{array}$ & Area & $\begin{array}{c}\text { Day time dB } \\
(7 \mathrm{am} \text { to } \\
10 \mathrm{pm})\end{array}$ & $\begin{array}{l}\text { Night time } \\
\text { dB }(10 \mathrm{pm} \\
\text { to } 7 \mathrm{am}) \\
\end{array}$ \\
\hline $\mathrm{A}$ & Industrial & 75 & 70 \\
\hline $\mathrm{B}$ & Commercial & 65 & 55 \\
\hline $\mathrm{C}$ & Residential & 55 & 45 \\
\hline $\mathrm{D}$ & Silent & 50 & 40 \\
\hline
\end{tabular}

Table 1 shows the noise level during the Ganesh Festival from 14 to 23 September 2018. During this period the noise level were exceeding the limit which were compared with the noise level standards prescribed by CPCB. As per CPCB norms the noise level for residential zone is $55 \mathrm{~dB}$ for day time and $45 \mathrm{~dB}$ for night time. Hence the Leq is more than the norms during day time. The highest reading ( $95.48 \mathrm{~dB})$ was recorded on $16^{\text {th }}$ September 2019 while another reading are also crossing the normal limits of noise. Dubal, R. S. et.al (2017) also noted high level noise pollution in Satara city during ganesh festivals. The maximum noise level observed in this study was due to public visit, DJ systems used and heavy traffic. Their study reported that the noise level observed in the residential and commercial area is near about two time permissible limits stated by WHO and BIS. This study concluded that it is important to control noise pollution at source, along the transmission path and at receivers end by using personal protective equipment. Same type of results reflected when Lad, R. J. et.al in 2012 monitored noise at ten locations in Kolhapur city of residential, commercial, industrial and silence zones during diwali festival. Which were found high compared to the prescribed CPCB limits except industrial zone. They also stated that there should be a need of awareness among people and Government officials about prevention of noise pollution.

\section{CONCLUSION}

This study concluded that noise level is increased during Ganesh festival which is compared with prescribed Central Pollution Control Board standards. In general observation of the study, it is concluded that the Leq has been increased due to the use of various types of music systems, human activities and increase in human population (crowd) during the ganesh festival in Kolhapur City. In general observation of the study, it was noted that the Leq has been increased due to the use of various types of music systems, human activities and increase in human population i.e. crowd during the ganesh festival in Kolhapur City.

\section{REFERENCE}

[1] Rane P., Joshi A. N., and Joshi N. C. (2012). Study of Noise Levels in Mumbai on Diwali Festival Day and Night time, International Journals of Environmental Sciences. 1(4)349-354.

[2] Hunashal R. B., and Patil Y. B. (2011). Environmental Noise Pollution in Kolhapur City". An International Quarterly Scientific Journal. 10 (1) 39-44

[3] Dubal R. S., Kamble, K. J. (2017). Study of Noise Level during Ganesh Festival in and around Satara City, International Journal of Researches in Bioscience, Agriculture and Technology. V(1).19-21.

[4] Manglekar S. B., Jadav, A. S. and Raut, P. D. (2012) Study Of Noise Pollution in Kolhapur City, Maharashtra, India Universal Journal of Environmental Research and Technology. 2(1).65-69.

[5] Lad R. J. Patil, V. N. and Raut, P. D. (2012) Study of Noise Pollution during Deepawli festival in Kolhapur city of Maharashtra, India Review of Research. 1 (V).1-4.

[6] Patel N. L. and Bhave P. P. (2014). Study of Noise Pollution during Deepawali Festival. International Journal of Innovative Research in Advanced Engineering. 1(6)1-4. 
International Journal of Trend in Scientific Research and Development (IJTSRD) @ www.ijtsrd.com eISSN: 2456-6470

[7] Vijendra M. (2006).“Environmental Noise Pollution Causes, Evils, Legislation and Control”. Deep and Deep Publication Pvt. Ltd.

[8] Basak A. (2009), "Environmental Studies". $1^{\text {st }}$ edition, Dorling Kindersley (India) Pvt., Ltd.
Copyright (C) 2019 by author(s) and International Journal of Trend in Scientific Research and Development Journal. This is an Open Access article distributed under the terms of the Creative Commons Attribution License (CC BY 4.0) (http://creativecommons.org/licenses/by/4.0)

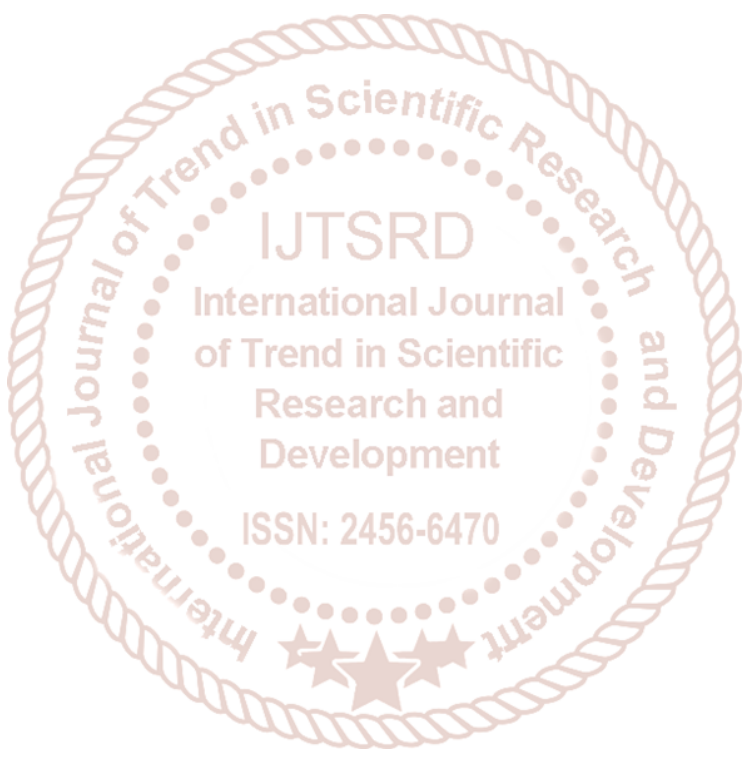

